\title{
AUTONOMOUS AND COLLECTIVE SANCTIONS IN THE INTERNATIONAL LEGAL ORDER
}

\author{
NigEL D. WHITE*
}

\begin{abstract}
The UK government is currently proposing the enactment of a "Sanctions Act" upon the UK's withdrawal from the EU in 2019, embodying a right to impose "autonomous sanctions" against other states and non-state actors, on the basis that the UK will no longer be able to benefit from the EU's collective sanctioning competence. The spotlight is again on the nature and purposes of sanctions in international law. The article addresses the legal framework applicable to sanctions by, first of all, showing that the nature of sanctions is different in the international legal order to how it is conceived in domestic legal orders in that sanctions are primarily imposed in response to threats to or breaches of the peace and, in so doing, the analysis will distinguish sanctions from countermeasures and other non-forcible measures. It then proceeds to demonstrate that the values of peace and security that underpin sanctions are essentially normative and should be seen as part of the international legal order and enforceable through sanctions alongside other fundamental norms of international law. Whether viewed as responses to breaches of international law or not, the analysis shows that sanctions are collective measures exclusively within the competence of international organizations. Having established the conceptual and legal frameworks for understanding sanctions, the article considers sanctions imposed against states and non-state actors, and explores whether the move towards targeted sanctions is a form of collective response to violations of international law. The article finishes by considering that, in contrast to countermeasures and other measures of self-help, collective sanctions are inherently lawful, but can only be legally justified as measures adopted out of a necessity to prevent major ruptures to peace and international law.
\end{abstract}

Keywords: autonomous sanctions; collective sanctions; countermeasures; collective countermeasures; United Nations; Security Council; European Union; United States

\section{INTRODUCTION}

Sanctions are embedded in international relations but their status in international law is often controversial. In this context it is worth considering the UK government's response to its consultation of 2017 on the "future legal framework for imposing and implementing sanctions", which would follow from the UK's withdrawal from the EU in 2019, and consequent inability to help shape, or rely on, the EU's sanctioning powers. The UK government states that the "UK needs to be able to impose and implement sanctions in order to comply with our obligations under the [...] UN Charter and to support our wider foreign policy and national goals. Many of our current sanctions regimes are established via powers in the European Communities Act 1972 (ECA) so we will need new legal powers to replace those

\footnotetext{
* Professor of Public International Law, University of Nottingham, UK. Email: nigel.white@nottingham.ac.uk.
} 
once the ECA is repealed". ${ }^{1}$ In the White Paper of April 2017 that shaped the consultation, the government stated that "when the UK withdraws from the EU we will need new legal powers that are compliant with our domestic legal system"; these powers "will enable us to preserve and update UN sanctions, and to impose autonomous UK sanctions in coordination with our allies and partners". 2

The idea that powers belonging to the EU as an international organization with separate legal personality could be straightforwardly claimed by the UK as a non-EU member state, in the form of a proposed "Sanctions Act", ${ }^{3}$ does not withstand scrutiny unless there is a separate international, and not merely national, legal basis for such "autonomous" sanctioning powers. It is interesting that the UK did not feel the need to claim an international legal basis for autonomous sanctions (i.e. those imposed outside of the UN Charter or the EU Treaties), when the doctrine of countermeasures might have provided an obvious, though problematic, legal basis. The UK's failure to put forward an international legal basis might be due to the fact that it views sanctions as something much broader than temporary and proportionate non-forcible measures taken in response to a violation of international law (countermeasures). It certainly suggested this by depicting sanctions as "an important foreign policy and national security tool", which "can be used to coerce a change in behaviour, to constrain behaviour by limiting access to resources, or to communicate a clear political message". 4

It follows the UK government views sanctions as distinct from countermeasures and other non-forcible measures of self-help by linking sanctions to its foreign policy and security and not just as responses to violations of the UK's international legal rights by another state. This article shows that while the UN and EU have autonomous sanctioning powers, individual states do not possess them beyond limited rights of self-help most clearly embodied in the doctrine of countermeasures taken in response to breaches of their international rights by other states. However, in asserting a wider autonomous sanctioning right, the UK will be joining the US in this regard as advocates of unilateral sanctions.

The article addresses the legal framework applicable to sanctions by, first of all, showing that the nature of sanctions is different in the international legal order to how it is conceived in domestic legal orders in that sanctions are primarily imposed in response to threats to or breaches of the peace and, in so doing, the analysis will distinguish sanctions from countermeasures. It then proceeds to demonstrate that the values of peace and security that underpin sanctions are essentially normative and should be seen as part of the international legal order and enforceable through sanctions alongside other fundamental norms of international law. Whether viewed exclusively as responses to breaches of international law or not, the analysis shows that sanctions are collective measures exclusively within the competence of international organizations. Having set up the conceptual and legal frameworks for understanding sanctions, the article considers sanctions imposed against states and nonstate actors, and explores whether the move towards targeted sanctions is a form of collective response to violations of international law. The article finishes by considering that, in contrast

\footnotetext{
${ }^{1}$ HM Government, "Public consultation on the United Kingdom's future legal framework for imposing and implementing sanctions: Government response", August 2017, para I.1, available at: <https://assets.publishing.service.gov.uk/government/uploads/system/uploads/attachment_data/file/635101/cons ultation-uk-future-legal-framework-sanctions-government-response.pdf >.

${ }^{2}$ HM Government, "Public consultation on the United Kingdom's future legal framework for imposing and implementing sanctions", April 2017, p.7, available at: <https://assets.publishing.service.gov.uk/government/uploads/system/uploads/attachment_data/file/609986/Publ ic_consultation_on_the_UK_s_future_legal_framework_for_imposing_and_implementing_sanctions__Print_pd f_version_.pdf>.

3 "Public consultation", cit. supra note 1, para I.2.

4 "Public consultation", cit. supra note 2, p. 6.
} 
to countermeasures, collective sanctions are inherently lawful, but can only be legally justified as measures adopted out of necessity to prevent major ruptures to peace and international law.

\section{INTERNATIONAL LAW AND SANCTIONS}

Sanctions were defined by the Royal Institute of International Affairs in 1938 as "measures taken in support of law" that "are applied with and by the general authority, not by any individual". 5 This definition went further and stated that "with the substitution of the word 'state' for the word 'individual' this is true [...] of the sanctions of international, as well as national, law". 6 The key feature is that sanctions are imposed by a central authority, a feature that is given even greater emphasis in this definition than the events that trigger the sanctions themselves. However, this is not without objection since it has already been seen that the UK along with along with the US, ${ }^{7}$ argues that measures taken by individual states without any authorization from the UN or regional organization, can constitute "autonomous sanctions". This, as shall be seen, is a term which is used in a broader sense than "countermeasures", which are responses to breaches of a state's international rights by other states in the form of temporary and proportionate counter-breaches. It is also a term that overlaps with but remains distinct from acts of "retorsion", which are unfriendly acts of "discourtesy or unfriendliness" that are not inconsistent with the initiating state's existing obligations, and are not necessarily taken in response to breaches by the target state though they often will be. ${ }^{8}$ Non-forcible measures are thus a disputed aspect of international law even though there is a great deal of practice of them by states as well as international organizations.

Even before an understanding of "sanctions" in international law can be achieved, there is an extensive, if rather inconclusive, jurisprudential debate as to whether sanctions are a central part of any legal system or, indeed, a definition of law. Without undertaking an exhaustive philosophical exposition it is worth contrasting some of these views because the debates shed light on whether sanctions are viewed as an element of law or as responses to its breach. Nineteenth century English legal positivism depicted law as the command of a sovereign backed by a sanction, ${ }^{9}$ thereby making the sanction element not only a method of enforcement but an essential element of the law. Indeed, because of its lack of "command", "sovereign" as well as "sanction", Austin was of the view that international law was not law "properly so-called" and instead dismissively equated it with the laws of fashion in this regard. ${ }^{10}$

In contrast, twentieth century positivism as portrayed by Hart did not regard sanctions as central to the concept of law, dismissing theories of law as "coercive orders" that meet "at the outset with the objection that there are varieties of law found in all systems which, in three principal respects, do not fit this description", for example those conferring powers upon legal persons. ${ }^{11}$ Indeed, for Hart, international law is the paradigmatic set of laws that lack a

${ }^{5}$ GRANT and BARKER, Parry and Grant Encyclopaedic Dictionary of International Law, 3rd ed., Oxford, 2009, p. 539.

${ }^{6}$ Ibid.

${ }^{7}$ DAMROSCH, "Enforcing International Law through Non-Forcible Measures”, RCADI, Vol. 269, 1997, p.

9 ff., pp. 99-101; LOWENFELD, "Unilateral versus Collective Sanctions: An American's Perception" , in GowlLAND-DebBas (ed.), United Nations Sanctions and International Law, The Hague, 2001, p. 95 ff.

${ }^{8}$ RUYS, "Sanctions, Retorsions and Countermeasures", in VAN DEN HERIK (ed.), Research Handbook on UN Sanctions and International Law, Cheltenham, 2017, p. 19 ff., p. 24.

${ }^{9}$ PENNER, McCoubrey and White's Textbook on Jurisprudence, 4th ed., Oxford, 2008, p. 37.

${ }^{10}$ AUSTIN, The Province of Jurisprudence Determined, London, 1832, lecture 1.

${ }^{11}$ HART, The Concept of Law, 3rd ed., Oxford, 2012, p. 48. 
centralized enforcement or sanctioning element. ${ }^{12}$ Schachter reinforced this view by pointing to UN practice that for much of the Cold War concentrated on lawmaking without much regard to compliance, enforcement or sanctions. ${ }^{13}$ Others such as Brierly and Kunz agree that the international legal system is a primitive one in which highly decentralized sanctions do exist, but argue that their application was left to the legal persons in that system, namely sovereign states. ${ }^{14}$ It can be seen that, as well as disagreement about the centrality of sanctions to an understanding of law, there is a division between those jurists who see centralization in some shape or form as being integral to sanctions, while others see them being directly imposed by states.

However, it is true to say that modern international law, especially after the Cold War, has witnessed both an increased institutional sanctions usage, and a clarification of the law concerning unilateral non-forcible measures. There is a growing understanding of the distinction between collective sanctions and unilateral countermeasures; the former being deployed for the "public" enforcement of community based norms, while the latter are used for the "private" enforcement of bilateral norms. Unilateral victim state responses to breaches of legal duties owed by another state are seen as non-forcible reprisals or, to use the modern term, countermeasures; whereas sanctions are a collective power given by groups of states to international organizations, namely the UN and regional organizations. In this vein, Abi-Saab defined sanctions as "coercive measures taken in execution of a decision of a competent social organ, i.e. an organ legally empowered to act in the name of the society or community that is governed by the legal system". Sanctions are distinct from "coercive measures taken individually by States or group of States outside a determination and a decision by a legally competent social organ". Such reprisals, countermeasures and acts of retorsion "are manifestations of 'self-help' or 'private justice', and their legality is confined to the very narrow limits within which 'remnants' of 'self-help' are still admitted in contemporary international law". ${ }^{15}$

Despite the post-1945 proliferation of international organizations, the ILC's Articles on the Responsibility of States for Internationally Wrongful Acts of 2001 did not include sanctions in its system of secondary rules, only countermeasures as a bilateral means of law enforcement in a decentralized system, ${ }^{16}$ where an injured state "may seek to vindicate their rights and to restore the legal relationship" with the responsible state, a relationship that "has been ruptured by" an unlawful act. ${ }^{17}$ As noted by Alland, "countermeasures are a mechanism of private justice", which produce "contradictions inherent in a self-assessed (i.e. auto-interpreted or auto-appreciated) decentralized policing of an international ordre public". ${ }^{18}$ Provost is even more explicit in depicting the weaknesses of such a system when he writes that "the right of states unilaterally to assess a breach by another state and to validate what would otherwise be an illegal act has the potential of significantly destabilizing international relations". ${ }^{19}$ The depiction of states' use of countermeasures as a form of policing, albeit of a potentially

12 Ibid., pp. 216-220.

${ }^{13}$ SCHACHTER, “United Nations Law”, AJIL, 1994, p. 1 ff., pp. 9-10.

14 BRIERLY, "Sanctions", Transactions of the Grotius Society, 1932, p. 68 ff.; KUnZ, "Sanctions in International Law”, AJIL, 1960, p. 324 ff.

15 ABI-SAAB, "The Concept of Sanction in International Law", in GowLLAND-DEBBAS (ed.), cit. supra note 7, p. 32 ff., p. 38. See further ZoLler, Peacetime Unilateral Remedies: An Analysis of Countermeasures, Dobbs Ferry, NY, 1984, p. 106.

${ }^{16}$ Articles on Responsibility of States for Internationally Wrongful Acts (ARSIWA), 2001, Arts. 49-54.

${ }^{17}$ CRAWFORD, The International Law Commission's Articles on State Responsibility, Cambridge, 2002, p. 281.

${ }^{18}$ Alland, "The Definition of Countermeasures", in CRAWfORD, PELleT and Olleson (eds.), The Law of International Responsibility, Oxford, 2010, p. 1127 ff., pp. 1223-1235.

${ }^{19}$ Provost, State Responsibility in International Law, Aldershot, 2002, p. xv. 
destabilizing kind, of an international ordre public is blurring countermeasures which are an auto-interpretive mechanism of law enforcement of bilateral rights and duties, with sanctions which are a collective response to threats to the public order, peace and stability of states. It is worthwhile hypothesizing about why the ILC did not include the notion of sanctions within its secondary rules on state responsibility by suggesting that sanctions were beyond the ILC's remit given their more fundamental role as measures for preserving peace and security, and not just as secondary responses to breaches of the primary rules of international law. ${ }^{20}$

The distinction between "public" sanctions and "private" countermeasures is relatively straightforward to make when considering the paradigmatic instances of each. However, the concept of countermeasures as depicted by the ILC is very narrow and does not capture the range of state practice on unilateral non-forcible measures and other forms of economic coercion. ${ }^{21}$ Bederman suggests that "the central conceptual mission" of the ILC's Articles on countermeasures was "the search for a polite international society". ${ }^{22} \mathrm{He}$ contends further that the Articles on countermeasures represent a "profound impulse toward social engineering for international relations [...] imagining a time in international life when unilateral and horizontal means of enforcement through robust self-help will be a thing of the past". ${ }^{23}$ The narrow clarity of the ILC's Articles on countermeasures leaves a great deal of practice on non-forcible forms of coercion unregulated by international law. ${ }^{24}$

Despite Hart's view that international law epitomises a diffused reactive legal system, ${ }^{25}$ the evidence is that there has been greater centralization of sanctions in the international legal order than the pure customary system depicted by Hart, and that sanctions adopted by those centralized organs are both lawful and legitimate. Moreover, such sanctions are the only clear forms of lawful non-forcible measures designed to enforce community norms. Private justice is left in the hands of states that want to respond to a breach of a bilateral legal relationship with another state; these responses are seen as acts of self-help not autonomous sanctions. The problem is that there is a grey area in between collective sanctions and unilateral countermeasures, where states make a range of claims to be able to take non-forcible measures, which are either depicted as "collective countermeasures" or "autonomous sanctions" taken by states in response to what each participating state perceives as a breach of community norms or, indeed, threat to national interests. The use of the term "collective" in connection with "countermeasures" should not disguise the fact that such measures are not institutional and may well be adopted by each sanctioning state independently of any other. In fact the term "autonomous sanctions" more fairly embodies the type of power being claimed by states as a right exercised independently from any international organization.

\section{SANCTIONS: ENFORCING PEACE OR LAW?}

According to Kelsen "law is, by its very nature, a coercive order". ${ }^{26}$ For Kelsen sanctions are integral to law in that law specifies the proscribed behaviour and also the response to such

${ }^{20}$ CRAWFORD, cit. supra note 16, p. 168, p. 282, preferring the term "measures" to "sanctions".

${ }^{21}$ ElAGAB, The Legality of Non-Forcible Counter-Measures in International Law, Oxford, 1988, pp. 212213.

${ }^{22}$ BEDERMAN, "Counterintuiting Countermeasures", AJIL, 2002, p. 817 ff., p. 819.

${ }^{23}$ Ibid., p. 831.

${ }^{24}$ RUYS, cit. supra note 8, p. 24.

${ }^{25}$ HART, cit. supra note 11, p. 213.

${ }^{26}$ KELSEN, The Law of the United Nations, New York, 1950, p. 706. ID. , Principles of International Law, New York, 1966, p. 22. 
behaviour. ${ }^{27}$ Kelsen was clear that the same conception applies to a legal order providing for collective security when we wrote that "a social order guaranteeing collective security is by its very nature a legal order, and a legal order is a system of norms providing for sanctions". ${ }^{28}$ While this appears to be more difficult to sustain at the international level where the sanction element of any law is often unspecified or unused, Kelsen's analysis of sanctions is a normative one meaning that sanctions ought to be imposed not that they will be.

Even in theories such as Hart's, in which sanctions are not viewed as primary rules themselves, they are seen as a form of punishment or response to breaches of those rules, responses that become more centralized as the legal system develops from a primitive set of primary rules. ${ }^{29}$ In Hart's words: "most systems have, after some delay, seen the advantages of further centralization of social pressure; and have partially prohibited the use of physical punishments or violent self-help by private individuals". Instead, legal systems have "supplemented the primary rules of obligation by further secondary rules, specifying [...] the penalties for violation", including an "exclusive power" conferred on officials of the system to impose penalties. "These secondary rules provide the centralized official 'sanctions' of the system". ${ }^{30}$

The issue of whether sanctions are primary rules of international law or secondary rules of responsibility where they would sit alongside countermeasures remains under-analysed, but certainly for Kelsen a sanction is part of the law not simply a consequence of its breach. Furthermore, according to Kelsen, and implicitly for most commentators, sanctions are "coercive reactions against an actual violation of the law", or alternatively, against suspected or expected violations. ${ }^{31}$ This formulation does allow for some anticipatory sanctions, but the triggers remain actual or potential violations of the law. In contrast, it is clear that in the international legal order, especially in its collective security component, "sanctions" are not confined to actual or potential violations of international law, rather the primary triggers are actual or threatened ruptures of the peace. In this way they reinforce the basic pre-conditions necessary for any legal order to exist. Kelsen accepts that legal systems generally recognise the legitimacy of coercive measures that have no relation to actual or potential violations of the law but, nevertheless, remain necessary to maintain or restore peace and security.

However, the examples given by Kelsen show that this is the exception rather than the rule within national legal orders; his examples of when sanctions may be imposed for reasons of necessity include the forcible destruction of buildings to prevent the spread of fire, or the forcible internment of people suffering infectious diseases in order to prevent an epidemic from spreading. ${ }^{32}$ Arguably, in the international order, these sorts of exceptions are the norm so that sanctions are imposed by the UN Security Council to address threats to the peace, ${ }^{33}$ whether or not those threats entails actual or possible violations of the law. ${ }^{34}$ A different way of looking at it would be to see sanctions being directed at shoring up the basic conditions of peace and security necessary for a legal order to survive, thereby making sanctions part of the legal order. Kelsen does not go quite this far, but accepts that 'by declaring the conduct of a state to be a threat to, or breach of, the peace, the Security Council may create new law', imposing an 'obligation to refrain from this conduct'. ${ }^{35}$

${ }^{27}$ KELSEN, "The Pure Theory of Law, Its Method and Fundamental Concepts", Law Quarterly Review, 1934, p. 474 ff., pp. 484-485.

${ }^{28}$ KELSEN, Collective Security under International Law, Washington DC, 1957, p. 101.

${ }^{29}$ HART, cit. supra note 11, pp. 91-99.

${ }^{30}$ Ibid., pp. 97-98.

${ }^{31}$ KELSEN, cit. supra note 28, p. 102.

${ }^{32}$ Ibid.

${ }^{33}$ Charter of the United Nations, 24 October 1945, 1 UNTS XVI, Art. 39.

${ }^{34}$ KUNZ, cit. supra note 14, p. 329.

${ }^{35}$ KELSEN, cit. supra note 26, p. 736. 
For Gowlland-Debbas, however, sanctions are an aspect of the "creation of international institutional responses to violations of [...] core norms". She argues that although Chapter VII measures imposed by the Security Council were not intended to be restricted to cases of noncompliance with international law, the practice of the Council has moved considerably towards using its powers to address the responsibility of states for breaches of core norms of international law. ${ }^{36}$ In a sense this anticipates the arguments for a Responsibility to Protect in international law emerging in 2001 with the proposition that when a state has failed to protect its population from the commission of core crimes then a responsibility lies with the Security Council to take measures, a proposition that remains de lege fereda. ${ }^{37}$ While it is argued in this article that sanctions against states remain primarily designed to tackle threats to or breaches of international peace and security, and only secondarily law, the development of sanctions against non-state actors is indicative of a trend towards punishment for violations of the law, given that this development has occurred against the background in international law and institutions of a move towards addressing individual responsibility for core crimes. Nonetheless, sanctions against non-state actors remain a mixture of enforcing peace and law but their primary purpose is the former. ${ }^{38}$

Arguably the norms of the international ordre public are not only jus cogens norms, but are also those supporting the normative concepts of "peace" and "security", where both nonforcible and forcible sanctions are essential components of those norms. If then "peace" and "security" are considered fundamental norms of the international legal order underpinning those proscribing "aggression", "genocide" and "crimes against humanity", then the role and functions of sanctions in their enforcement can be considered as intra-legal issues. This contrasts with the orthodoxy where sanctions taken for the purposes of securing peace and security are seen in part as extra-legal, embodied in the statement by Kelsen that the purpose of enforcement "is not to maintain or restore law, but to maintain or restore peace, which is not necessarily identical with the law". "However, although it is common to see discussion of "peace" and "security" as international norms in international relations discourse, ${ }^{40}$ they are not seen in this way in international law where states are protected from "aggression" or "uses of force" as peremptory norms, narrower concepts than "threats to or breaches of peace and security". The latter norms are protected to some extent by the Security Council, ${ }^{41}$ but are traditionally seen as coming within that's organ's political discretion rather than its legal obligations, ${ }^{42}$ despite that organ having "primary responsibility for the maintenance of international peace and security", with ensuing "duties". ${ }^{33}$

One obvious objection to the inclusion of the norms of "peace" and "security" in the hierarchy of international law is their apparent subjectivity. ${ }^{44}$ The debates about what is a "threat to the peace", even a "breach of the peace" within the meaning of Article 39, are well

${ }^{36}$ Gowlland-DebBas, "UN Sanctions and International Law: An Overview", in Gowlland-DeBBAS (ed.), cit. supra note 7, p. 1 ff., pp. 7-9; GowLlAND-DEBBAS, "Security Council Enforcement Action and Issues of State Responsibility", ICLQ, 1994, p. 55 ff.

37 FOCARELLI, "The Responsibility to Protect Doctrine and Humanitarian Intervention: Too Many Ambiguities for a Working Doctrine”, Journal of Conflict \& Security Law, 2008, p. 191 ff.

${ }^{38}$ WHITE, "Sanctions against Non-State Actors", in RonZITTI (ed.), Coercive Diplomacy, Sanctions and International Law, Leiden, 2016, p. 127 ff., pp. 135-138.

${ }^{39}$ KELSEN, cit. supra note 26, p. 294.

40 FOOT and WALTER, "Global Norms and Major State Behaviour: The Case of China and the United States”, European Journal of International Relations, 2012, p. 1 ff., p. 6.

${ }^{41}$ UN Charter, Art. 39.

${ }^{42}$ KELSEN, cit. supra note 26, 733.

${ }^{43}$ UN Charter, Art. 24(1).

${ }^{44}$ BUZAN, WAEVER, and DE WILDE, Security: A New Framework for Analysis, Boulder, 1998, pp. 23-26. 
known, ${ }^{45}$ but the fact is that the Security Council in determining that a threat exists and then imposing sanctions on a target state or individual, has both determined the law and enforced it. ${ }^{46}$ Despite its unappealing nature, at least to believers in objective laws, ${ }^{47}$ this form of constructivist inter-subjective agreement arguably enables international law to develop to achieve new understandings of security in an ever-changing world. ${ }^{48}$

In order to ensure the survival of the planet, more specifically the system of international relations based on nation-states, states and other key actors take measures to establish the basic conditions for the control of violence. Without controlling and containing violence in international relations it would not be possible to establish a viable international political and legal order. Overall, the aim of collective measures such as sanctions is to reduce the levels of violence between states, and increasingly within states and against civilian populations (the achievement of peace); by addressing existential threats to states, peoples and groups (the achievement of security).

Historically, peace has been equated to the absence of wars; and security was viewed as the security of states from aggression by other states; ${ }^{49}$ and international laws and structures have reflected this. However, as international laws and institutions have been strengthened in response to major ruptures of international peace, especially at the end of major conflicts with the creation first of the League of Nations and then the UN, there has been a deepening of the international consensus on what is meant by peace and security, ${ }^{50}$ to cover sustainable peace within and between states, and the security of groups and individuals as well as states. ${ }^{51}$ Having said that, it is true to say that international law remains based on state-security, reflected in fundamental inter-state compacts, and has been reinforced by a continued state-based monopoly on the means of using force. ${ }^{52}$ However, changes in the understanding of state sovereignty mean that it is no longer absolute, rather it is qualified by a responsibility towards civilian populations leading to debates as to where responsibility to protect the population falls when the home government fails to act to stop core crimes being committed. ${ }^{53}$

The problem remains that measures taken to enforce the peace and security between states or within states are not seen as measures to enforce the law and, therefore, are kept distinct from our inherent notion that sanctions are taken to do just that. ${ }^{54}$ However, a reconceptualization of "peace" and "security" as normative concepts that are actually fundamental principles of the international legal order would make the framing of sanctions, the analysis of them, and issues of their compliance with other laws, principally one of law. ${ }^{55}$

$45 \mathrm{KRISCH}$, “Article 39", in Simma (ed.), The Charter of the United Nations: A Commentary, 3rd ed., Oxford, 2012, p. 1272 ff., pp. 1278-1294.

${ }^{46}$ OraKhElashVILI, Collective Security, Oxford, 2011, p. 189.

${ }^{47}$ KoskenNIEMI, The Gentle Civilizer of Nations: The Rise and Fall of International Law 1870-1960, Cambridge, 2001, p. 188.

${ }^{48}$ HuRD, International Organizations: Politics, Law and Practice, 2nd ed., Cambridge, 2011, p. 24.

49 Rothwell, ScotT and Hemmings, "The Search for 'Antarctic Security", in HeMmings, Rothwell and ScOTT (eds.), Antarctic Security in the Twenty-First Century, London, 2012, p. 1 ff., p. 3.

${ }^{50}$ NASU, "Law and Policy for Antarctic Security: An Analytical Framework", in HEMMINGS, RothwELL and SCOTT (eds.), cit. supra note 49, p. 18 ff., p. 24.

51 Note by the President of the Security Council, The Responsibility of the Security Council in the Maintenance of International Peace and Security, 31 January 1992, UN Doc S/23500, OXIO 127; FALK, On Humane Governance: Toward a New Global Politics, London, 1995, p. 147; HAMPSON, "Human Security", in WiLliams (ed.), Security Studies: An Introduction, London, 2008, p. 229 ff., p. 231.

52 WEBER, "Excerpts from Politics as a Vocation", in LEMERT (ed.), Social Theory: The Multicultural and Classic Readings, Boulder, 1999, p. 111; KRAHMANN, "Private Security Companies and the State Monopoly on Violence: A Case of Norm Change?", PRIF-Reports No. 88, 2009, p. 2, available at: <https://www.hsfk.de/fileadmin/HSFK/hsfk_downloads/prif88_02.pdf>.

532005 World Summit Outcome, UN Doc. A/RES/60/1 (2005), paras. 138-139.

${ }^{54}$ FARRALL, United Nations Sanctions and the Rule of Law, Cambridge, 2007, p. 7.

55 Tsagourias and White, Collective Security: Theory, Law and Practice, Cambridge, 2013, pp. 32-37. 
This has the advantage of being able to judge the institutions adopting sanctions by standards of law rather than solely by reference to standards of effectiveness and impact. As long as "peace" and "security" remain outside mainstream international law there will be a tension and confusion between the political discretion at the heart of sanctions and understanding that sanctions are essentially legal-coercive means to ensure that laws are complied with and the basic conditions of peace and security necessary for the continued existence of the legal order are maintained.

\section{SANCTIONING AUthORITIES}

Thus far, the understanding of sanctions is of non-forcible measures imposed by centralized authorities in response to breaches of peace, security and, increasingly law, while countermeasures and other acts of non-forcible self-help are imposed by a state in responses to breaches of law suffered at the hands of another state. Collective countermeasures blur this distinction to some extent in that they represent non-forcible attempts by non-victim states to enforce self-defined community norms outside of the institutional collective security regime and the bilateral mechanisms of normal countermeasure. ${ }^{56}$

In theory, sanctions imposed by organizations and countermeasures imposed by states are distinct. ${ }^{57}$ However, if a collective right to take countermeasures is recognized, whereby states are permitted to take measures against a state in breach of obligations owed erga omnes i.e. to the whole international community, the line between countermeasures and sanctions appears less clear. Nevertheless, the concepts of collective sanctions and collective countermeasures are not the same, given that countermeasures, whether unilateral or collective, are rights of states to respond to violations of international law and signify temporary nonfulfilment of obligations owed by the victim state(s) to the responsible state; while sanctions are powers exercised by competent organizations that can go above and beyond suspending any existing obligations of states and, moreover, are not currently conceived primarily as punishments for violations of international law, but responses to threats to international public order. It follows that a sanctions regime could, like proportionate countermeasures, merely lead to the suspension of trade and arms agreements with a state; but it could go further and terminate those agreements and outlaw any further agreements on trade, arms or others areas such as technology and finance and, furthermore, could oblige all member states to adopt such measures.

The type of sanctions just described can only be applied lawfully by a few international actors, namely the UN Security Council under Chapter VII of the UN Charter, and regional organizations as identified under Chapter VIII of the UN Charter and empowered by their own constituent treaties. As such, sanctions are clearly the result of a significant attribution of powers by the member states to those organizations. The limited range of institutional actors with sanctioning competence is not only due to the hierarchy contained in the UN Charter, whereby regional organizations are limited in their enforcement powers by the authority of the UN Security Council, but also by the obligation on member states to give priority to obligations arising from the UN Charter over those arising from other treaties including regional ones. ${ }^{58}$

This explains which organizations have competence but it does not explain why states do not have such. That lack is because only the UN and competent regional organizations have

${ }^{56}$ KATSELl-ProukaKI, The Problem of Enforcement in International Law: Countermeasures, the NonInjured State and the Idea of International Community, London, 2010, pp. 90-209; DAWIDOWICZ, Third Party Countermeasures in International Law, Cambridge, 2017, pp. 3-5.

${ }^{57}$ ZOLLER, Peacetime Unilateral Remedies: An Analysis of Countermeasures, New York, 1984, p. 106.

${ }^{58}$ UN Charter, Arts. 53 and 103. 
the power to impose collective measures that bind all member states to impose non-forcible measures against a target state. No single state has the power to bind other states to act in this way, although they may try to enmesh other states and actors by including an extraterritorial element in unilateral non-forcible measures imposed on a target state. For instance, under the US Helms-Burton Act 1996 penalties for breach of the Cuban embargo (emplaced under Presidential Executive Order since 1962), ${ }^{59}$ for example importing into the US any goods of Cuban origin, in whole or in part, were increased. ${ }^{60}$ Specifically, Title III of the Act granted US citizens a remedy in domestic courts against anyone "trafficking" in property that was USowned before its seizure by the Cuban government in the early 1960s. This was one of the socalled extra-territorial effects of Helms-Burton objected to by the UK and EU amongst others as a breach of international laws limiting jurisdiction. ${ }^{61}$

Such over-reach is not an issue for most competent international organizations. Member states have not simply given the organization in question the right to take measures that each of them has individually, but have collectively given the organization a power to take measures against a target state that will require each member to adjust its diplomatic, financial, economic or sporting relations with the targeted state or non-state actor. No state has the power or right to ensure collective sanctions are taken under international law, although they have the right to take individual non-forcible countermeasures in response to violations of their rights by other states. $^{62}$

The UN Security Council is expressly empowered to impose non-forcible measures, including the "complete or partial interruption of economic relations and of rail, sea, air, postal, telegraphic, radio, and other means of communication, and the severance of diplomatic relations", in response to threats to the peace, breaches of the peace and acts of aggression. ${ }^{63}$ This power is granted to the organization, specifically the Security Council, by the founding states to use against a member state and to oblige other members to so act, ${ }^{64}$ although the almost universal nature of the UN has meant that the Council tends to imposes the obligations created by its non-forcible measures on all states, an extension that could be said to develop the obligation on the UN to ensure that non-member states act in accordance with the UN's principles "as far as may be necessary for the maintenance of international peace and security" ${ }^{65}$ Nonetheless, this falls short of imposing obligation on non-member states meaning that the UN's extension of its sanctions' obligations to "all states" is problematic, as nonmember states have not consented to the adoption of such measures. Arguments that the UN Charter is the constitution of the international community may help overcome this limitation but they have not been fully developed or explained. ${ }^{66}$

${ }^{59}$ Proclamation 3347 - Embargo on All Trade with Cuba, 3 February 1962, in which the President, acting under the Foreign Assistance Act 1961, prohibited "the importation into the United States of all goods of Cuban origin and all goods imported from or through Cuba".

${ }^{60}$ Cuban Liberty and Democratic Solidarity (Libertad) Act of 1996 (Helms-Burton Act), 110 Stat. 785, Section 110 (a).

${ }^{61}$ UK Protection of Trading Interests Acts 1980, applied by The Extraterritorial US Legislation (Sanctions against Cuba, Iran and Libya) (Protection of Trading Interests) Order 1996, SI 3171, to trade with Cuba; Council Regulation (EC) Regulation 2271/96, 22 November 1996. Both remain in force, though there has been little enforcement.

${ }^{62}$ But see MORRISON, "The Role of Regional Organizations in the Enforcement of International Law", in DELBRUCK (ed.), The Allocation of Law Enforcement Authority in the International System, Berlin, 1995, p. 39 ff., pp. 46-7, where he states that organizations cannot possess more powers than member states.

${ }^{63}$ UN Charter, Arts. 39 and 41.

${ }^{64}$ Ibid., Art. 25.

${ }^{65}$ Ibid., Art. 2(6).

${ }^{66}$ FASSBENDER, The United Nations Charter and the Constitution of the International Community, Leiden, 2009, p. 78. 
Examples of regional organizations with sanctioning competence include the Organization of American States (OAS) which, in response to any "fact or situation that might endanger the peace of America", ${ }^{67}$ is empowered through its Organ of Consultation to take the following non-forcible measures against member states: "recall of chiefs of diplomatic missions; breaking of diplomatic relations; breaking of consular relations; partial or complete interruption of economic relations or of rail, sea, air, postal, telegraphic, telephonic, and radiotelephonic or radiotelegraphic communications [...]". ${ }^{68}$ The African Union (AU), which replaced the Organisation of African Unity (OAU) in 2000, provides that "any Member State that fails to comply with the decisions and policies of the Union may be subjected to [...] sanctions, such as the denial of transport and communications links with other Member States, and other measures of a political and economic nature to be determined by the Assembly". ${ }^{6}$ The EU's sanctioning competence, however, is external facing and targeted at non-member states although they only bind EU member states. ${ }^{70}$ Given that these external measures do not bind the target state only EU member states, the lack of consent (to be bound) by the target state is not a legally insurmountable problem. However, assuming that a collective sanctioning power belongs to an organization for the purpose of controlling its membership, then the legal basis claimed for the EU's external measures is that they are a form of collective countermeasures. ${ }^{71}$ If the EU's external non-forcible measures extend beyond the doctrine of countermeasures the legal ground becomes more unstable in that they would represent steps towards claiming autonomous sanctioning powers by a regional organization.

Chapter VIII of the UN Charter governs relations between the UN and regional organizations. Under this framework regional organizations have autonomy in matters of peace and security "as are appropriate for regional action", as long as they act consistently with the purposes and principles of the UN Charter. Furthermore, disputes between states within the region should be subject to peaceful settlement attempts by the regional organization before any reference to the UN Security Council. ${ }^{72}$ As regards "enforcement action" by organizations for the purposes of collective or regional security, Article 53 of the Charter empowers the Security Council to utilize regional organizations for enforcement action taken under its authority, but clearly stipulates that "no enforcement action shall be taken" by regional organizations "without the authorization" of the UN Security Council. The ambiguity in the meaning of "enforcement action" is whether it covers both economic and military measures. ${ }^{73}$

Placing sanctions in the hands of central organs of a legal order is certainly the norm in modern domestic legal orders, but this has not been fully realized in the international legal order. For a start, sanctions are primarily adopted in response to threats to international public order, not breaches of international law. ${ }^{74}$ Furthermore, while the use of military force by states is ruled out by the UN Charter except in the exercise of the right of self-defence or under the authority of the Security Council ${ }^{75}$ there is no equivalent clear prohibition on states deploying autonomous non-forcible measures. ${ }^{76}$ It follows that while many domestic legal orders have Art. 29.

${ }^{67}$ Charter of the Organisation of American States, 30 April 1948, entered into force 13 December 1951,

${ }^{68}$ Inter-American Treaty of Reciprocal Assistance (Rio Treaty), 2 September 1947, Art. 8.

${ }^{69}$ Constitutive Act of the African Union, 1 July 2000, Art. 23(2).

${ }^{70}$ Treaty on European Union, 7 February 1992, Art. 29; Treaty on the Functioning of the European Union, 13 December 2007, Art. 215. See GeSTRI, "Sanctions Imposed by the European Union: Legal and Institutional Aspects", in RonZITTI (ed.), cit. supra note 39, p. 70 ff, p. 100.

${ }^{71}$ GESTRI, cit. supra note 70, p. 99.

${ }^{72}$ UN Charter, Art. 52.

${ }^{73}$ WALTER, “Article 53", in Simma (ed.), cit. supra note 45, p. 1478 ff., p. 1481.

${ }^{74}$ TSAGOURIAS and WHITE, cit. supra note 55, p. 224.

${ }^{75}$ UN Charter, Arts. 2(4), 42, 51 and 53.

${ }^{76}$ ElAGAB, cit. supra note 21. 
ruled out self-help, this has not happened in the international legal order at least in the case of non-forcible measures. Nonetheless, the supremacy of the Security Council should not be underestimated, given that it is empowered to adopt sanctions that oblige member states to take such measures against the target state, group or individuals in order to address threats to the peace. ${ }^{77}$ Finally, there is the aforementioned requirement that regional enforcement action needs authorization from the Security Council. ${ }^{78}$ The intention was to create supranational competence in the Security Council to oblige all member states (thereby having almost universal effect) to take non-forcible enforcement action, a competence not possessed by any other organization or actor, ${ }^{79}$ although regional organizations have carved out an autonomy to impose sanctions on their own membership by dint of consent (in the treaty) and practice. The EU's extra-regional application of sanctions is exceptional in this regard and can either be put down to a form of collective countermeasures or, most controversially, as a form of autonomous sanctions if they extend beyond the limitations upon countermeasures.

Gestri states that with over thirty sanctions programmes in place, often imposed autonomously from the UN Security Council, the EU has become a "key player in the sanctions game", and despite its claim to always act in full conformity with international law, the "EU can be regarded as a trailblazer by the advocates of the controversial doctrine of collective countermeasures in reaction to erga omnes obligations, having on numerous occasions adopted sanctions without being individually affected by the breach of international law allegedly committed by the target state" ${ }^{80}$ Furthermore, Gestri points to the pulling power of the EU on third states to bring their conduct vis a vis the target state into line with the EU's, ${ }^{81}$ and the broadening jurisdictional scope of EU sanctions in spite of its criticisms of the extraterritorial extension of sanction regimes by the United States. ${ }^{82}$ Collective countermeasures taken in response to violation of fundamental international laws remain controversial but, on a spectrum of legality, a reasonable argument can be made in their favour. In contrast, if sanctions going beyond countermeasures were to be imposed by the EU, it would become an even more controversial trailblazer for an autonomous external sanctioning power for regional organizations.

Institutional powers and practice on sanctions is difficult to reconcile with orthodox views of international law, where the state is the principal actor on the international stage with the most complete set of international rights and duties. Consequently, there have been attempts to rationalize the sanctioning power of organization by characterizing it as the collective application of rights belonging to states ${ }^{83}$ However, the cat was let out of the bag so to speak as soon the founding states adopted the UN Charter in 1945, placing sanctioning power in the hands of a separate corporate entity - the UN Security Council.

\section{MOVING The TARget BUt NOT THE PURPOSE}

Centralized institutional competence has been shown to have immense potential to impact upon states and other actors, although it remains incumbent on member states to carry out their obligations under the Charter or under regional treaties. If states do not fulfil their

\footnotetext{
${ }^{77}$ UN Charter, Arts. 25, 39 and 41.

${ }^{78}$ Ibid., Art. 53.

${ }^{79}$ SCHREUER, “Comments”, in DeLBRUCK (ed.), cit. supra note 62, p. 82.

${ }^{80}$ GESTRI, cit. supra note 70, p. 99.

${ }^{81}$ Ibid.

${ }^{82}$ Ibid., p. 79

${ }^{83}$ DOPAGNE, "Sanctions and Countermeasures by International Organizations", COLLINS and WHITE (eds.), International Organizations and the Idea of Autonomy: Institutional Independence in the International Legal Order, London, 2011, p. 178.
} 
obligations, sanctions remain symbolic. However, increasingly effective supervision and enforcement of sanctions has raised concerns about the legal parameters of such measures. Whether viewed as integral to law or a consequence of law's breach, collective sanctions are not unlawful per se, unlike countermeasures by states the wrongfulness of which is only precluded if they are taken in response to a prior breach of international law. ${ }^{84}$

So far we have seen that collective sanctions in the international legal order are imposed in response to, or to prevent, threats to or breaches of the peace which, at least in orthodox thinking, are not concepts embodied in law. However, given that sanctions are imposed to protect extra-legal values that ensure basic conditions of stability in the international order, it can be contended that they are primordially lawful actions. This section explores the move from general to targeted sanctions in order to ascertain whether a change in target has been accompanied by a change in purpose, namely from enforcing peace to enforcing law.

The rare instances of UN collective sanctions imposed during the Cold War had the appearance of community responses to violations of basic international laws respecting human rights and self-determination specifically by white racist regimes against the black majorities in Rhodesia and South Africa. However, a close reading of the applicable resolutions indicates that the measures were taken to tackle threats to international peace and security. The Security Council was careful to base its determinations of threats to the peace on a combination of the nature of the regimes, and the impact that those regimes' policies had on peace for the region, with evidence that internal violent struggles for freedom were spreading to neighbouring countries. This is clearly encapsulated in Resolution 418 (1977) imposing a mandatory arms embargo against South Africa in 1977, when the Security Council, "having regard to the policies and acts of the South African Government", determined that "the acquisition by South Africa of arms and related materiel constitutes a threat to the maintenance of international peace and security". Other resolutions adopted the typology of simply determining that the situation in Southern Rhodesia was a threat to international peace and security, ${ }^{85}$ thereby not linking the determination to anything other than peace and security.

The more recent turn to targeted sanctions imposed against non-state actors and regime elites are often explained as humane responses to concerns about the devastating effects of general sanctions imposed on Iraq to force it to withdraw from Kuwait following its aggressive occupation of that country in $1990,{ }^{86}$ and instead to target those individual violators of international standards and law. ${ }^{87}$ In fact, targeted sanctions were first imposed in the early 1990s against non-state actors who were in control of territory. In other words the rationale was similar to those sanctions imposed against states in terms of imposing measures against a territory and those groups exercising control over it in order to force them towards peace.

The early post-Cold War instances of sanctions against non-state actors were imposed against those holding power but who had not attained full status as state actors; measures in the 1990s were imposed against rebel groups with de facto belligerent status (e.g. UNITA in Angola and the Bosnian Serbs), or against de facto governments (e.g. the Taliban in Afghanistan). The measures against UNITA rebels were designed to force that armed group to accept the Peace Accords that it had previously signed but had breached through its continued military actions in Angola, thereby constituting a threat to international peace and security. ${ }^{88}$ UN collective sanctions taken against the Bosnian Serbs in the 1990s, the party to the conflict

\footnotetext{
${ }^{84}$ ARSIWA, Art. 22.

${ }^{85}$ UN Doc. S/RES/232 (1966).

${ }^{86}$ UN Doc. S/RES/661 (1990).

${ }^{87}$ Report of the Secretary-General's High-Level Panel on Threats, Challenges and Change, A More Secure World: Our Shared Responsibility, UN Doc. A/59/565 (2004), para. 179.

${ }^{88}$ UN Doc. S/RES/864 (1993).
} 
seen as acting most often in violation of international humanitarian law, ${ }^{89}$ remain measures aimed at restoring peace and security. While certain other non-forcible measures were taken on the basis that the violations of international law themselves constituted threats to the peace, particularly the creation of the ICTY,${ }^{90}$ non-forcible sanctions were imposed upon the Bosnian Serb leadership for refusing to settle peacefully and for continued fighting. In other words, they were designed to tackle the threat to the peace caused by the Bosnian Serbs' continued aggression and failure to accept various peace plans. ${ }^{91}$ Furthermore, the non-forcible measures taken by the UN Security Council to tackle violations of international law (viz. the establishment of the ICTY) were not targeted at the Bosnian Serbs leadership per se but at individual violators of international criminal law (including individuals from other armed groups as well as emerging states). That aspect of the threat arising from the violence in Bosnia and consisting of violations of international law was addressed by the creation of an international criminal tribunal with powers of punishment, while the continuing conflict and refusal by the Bosnian Serbs to settle peacefully were addressed by a variety of non-forcible and forcible measures imposed by the Security Council.

Even historically the first UN sanctions regime was imposed against the illegitimate white racist regime in Rhodesia in the late 1960s, a de facto government, though the measures imposed were not targeted and had a wider impact on the population. ${ }^{92}$ The first "generation" of smart sanctions against non-state actors in the 1990s were pragmatically driven measures against those in control of territories even though they had not achieved recognition as legitimate leaders of states. A clear departure from measures analogous to sanctions against states was only taken with the extension of the Taliban sanctions regime, imposed in 1999, to Al-Qaida in 2000 and, in so doing, removing the link between Al-Qaida and the territory of Afghanistan, ${ }^{93}$ followed in 2011 by the complete separation of the two regimes. ${ }^{94}$

A contrast can be made with EU sanctions which, because of the narrower consensus necessary to take decisions to impose measures and broader agreement on the values to be protected or promoted, show a faster and deeper trend towards sanctions directed at regime elites (for example, in Zimbabwe and Russia), ${ }^{95}$ and to a lesser extent non-state actors such as terrorist groups. ${ }^{96}$ For instance, targeted EU sanctions were initially imposed in 2002 by the Council against individuals in Zimbabwe on the basis of its assessment that the "Government of Zimbabwe continues to engage in serious violations of human rights and of the freedom of opinion, of association and of peaceful assembly". It decided that "for as long as the violations

${ }^{89}$ Final Report of the Commission of Experts Established Pursuant to Security Council Resolution 780 (1992), UN Doc. S/1994/674.

${ }^{90}$ UN Doc. S/RES/827 (1993). See also Appeals Chamber, Prosecutor v. Tadic, Case No. IT-94-1-IT, Judgment of 10 August 1995, para. 19.

${ }^{91}$ UN Doc. S/RES/942 (1994).

92 UN Doc. S/RES 232 (1966).

${ }^{93}$ UN Doc. S/RES/1267 (1999); UN Doc. S/RES/1333 (2000); FARRALL, cit. supra note 54, p. 131.

${ }^{94}$ UN Doc. S/RES/1988 (2011); UN Doc. S/RES/1989 (2011).

$95 \mathrm{See}$, for example, EU targeted sanctions against regime individuals in Zimbabwe (Council Decision 2011/101/CFSP of 15 February 2011, OJ L 42, p. 6), and Syria (Council Decision 2013/255/CFSP of 1 June 2013, OJ L 147, p. 14). Targeted sanctions were imposed against certain Russian individuals responsible for actions which undermined or threatened the territorial integrity, sovereignty and independence of Ukraine following intervention in Ukraine (Council Decision 2014/145/CFSP of 17 March 2014, OJ L 78, p. 16).

${ }^{96}$ Measures against Al Qaida in Common Position 2002/402/CFSP of 29 May 2002, OJ L 139, p. 4; measures against individuals and entities associated with Al Qaida in Council Regulation (EC) No 881/2000 of 29 May 2002, OJ L 139, p. 9. See also Common Position 2001/931/CFSP of 28 December 2001, OJ L 344, p. 93; Council Regulation (EC) No 2580/2001 of 28 December 2001, OJ L 344, freezing funds and economic resources of certain persons, groups and entities with a view to combating terrorism. 
occur the Council deems it necessary to introduce restrictive measures against the Government of Zimbabwe and those who bear a wide responsibility for such violations". ${ }^{97}$

The EU's measures are framed as a response to violations of international human rights standards occurring in Zimbabwe and, therefore, fit the prescription for collective countermeasures. In contrast, in the case of measures imposed by the US on Zimbabwe, in an Executive Order of 2003, the President "determined that the actions and policies of certain members of the Government of Zimbabwe and other persons to undermine Zimbabwe's democratic processes or institutions contributing to the deliberate breakdown in the rule of law in Zimbabwe, to politically motivated violence and intimidation in that country, and to political and economic instability in the southern African region, constitute an unusual and extraordinary threat to the foreign policy of the United States", and declared "a national emergency to deal with that threat". ${ }^{98}$ That formula of an executive Presidential Order, finding of a threat to the foreign policy and national security of the United States and declaring a national emergency to deal with the threat, has been used on a number of occasions by the US to tackle a variety of perceived threats by imposing targeted autonomous sanctions against individuals and other non-state actors. ${ }^{99}$ Less frequently, more normative based determinations of violations of human rights have been used by Congress to pass legislation imposing targeted sanctions. ${ }^{100}$ The Presidential executive power to impose sanctions, derived from the International Emergency Economic Powers Act (IEEPA) originally adopted in 1977, ${ }^{101}$ has been criticized on the grounds that "experience with IEEPA raises concerns that it may be used casually for spurious national emergencies". ${ }^{102}$ The language of the Presidential executive order on Zimbabwe also demonstrates that executive security powers are being invoked to tackle threats arising out of denial of democratic rights. The autonomous sanctioning right claimed by the United States is not just problematic under US constitutional law but, as the above analysis shows, is also unsupported in international law.

The analysis above demonstrates that the overriding purpose of general or targeted sanctions remains to change the behaviour of states or individuals either directly (to stop them for example from committing terrorist acts), or indirectly (to stop states or non-state actors supporting them). It follows that it is important to discern whether the sanctions are aimed at changing the behaviour that constitutes a threat to peace and security, or the behaviour that constitutes unlawful acts. ${ }^{103}$ The intended deterrent aspect of sanctions as punishment is to prevent future breaches of law, whereas the deterrent effects of sanctions to tackle threats to the peace is the immediate end of the behaviour that comprises the threat. Of course the dichotomy of what is a threat to the peace or what is a breach of the law is not always easy to maintain and criminal behaviour, particularly at the international level, can be a (part of) a wider threat to international peace. For instance, when imposing targeted measures against nonstate actors in the Central African Republic (CAR) the UN Security Council, acting under a general determination that the violence there constituted a threat to regional peace and stability,

\footnotetext{
L 50/1.

${ }^{97}$ Restrictive measures against Zimbabwe in Common Position 2002/145/CFSP of 21 February 2002, OJ

98 Executive Order 13288 - Blocking Property of Persons Undermining Democratic Processes or Institutions in Zimbabwe, 10 March 2003, 68 FR 11457.

99 See for example: Executive Order 13611 - Blocking Property of Persons Threatening the Peace, Security, or Stability of Yemen, 16 May 2012, 77 FR 29533; Executive Order 13338 - Blocking Property of Certain Persons and Prohibiting the Export of Certain Goods to Syria, 13 May 2004, 69 FR 26751; Executive Order 13067 - Blocking Sudanese Government Property and Prohibiting Transactions With Sudan, 5 November 1997, 62 FR 59989.

${ }^{100}$ Venezuela Defense of Human Rights and Civil Society Act of 2014, 128 Stat. 3011, S.2142.

10150 U.S.C. 35 (1982), Sections 1701-1702.

102 CARTER, "International Economic Sanctions: Improving the Haphazard U.S. Legal Regime", California Law Review, 1987, p. 1159 ff., p. 1238.

103 WHITE, cit. supra note 38, p. 136.
} 
imposed measures against individuals who were involved in planning, directing, or committing acts that violated international human rights law or international humanitarian law; ${ }^{104}$ as well as against individuals "engaging in or providing support for acts that undermine the peace, stability or security of the CAR, including acts that threaten or violate transitional agreements, or that threaten or impede the political transition process, including a transition toward free and fair democratic elections, or that fuel violence". ${ }^{105}$ This suggests that targeted sanctions are designed with a dual purpose in mind, to tackle breaches of the law as well as threats to the peace.

Nonetheless, the overriding purpose and design of sanctions remains to tackle threats to the peace. Cutting off the arms supply of an armed group, for example, is a sanction designed to reduce the danger to peace and security that group represents. Seizing the assets of members of that group, especially of those who have committed such alarming levels of violence as to constitute breaches of international law, may seem more like punishment for their unlawful acts, but it too is aimed at restricting their impact on peace, given that the members' fortunes and those of the group will be intimately connected, and cutting off individual's access to money will restrict their impact on peace. Restricting access to money and weapons will also help reduce violations of international humanitarian law committed by armed groups but this is a consequence of reducing the threat to peace and security by means of sanctions. Seen in this way, imposing measures against individuals who have committed violations of international law is primarily an attempt to stop the occurrence of violence, not to punish individuals for violations of the law resulting from that violence. If targeted sanctions are viewed as sanctions taken to punish the guilty, guilt has not been determined by any judicial procedure but by a political body. It may be sometimes that the resolutions of the Security Council appear to come close to this but the argument here is that such resolutions are best read through the lens of the Council's primary responsibility for peace and security. ${ }^{106}$

The predominance of sanctions adopted to preserve or restore peace and security is explicable because of the higher levels of violence within the international legal order justifying institutional competence to deal with what might be called the pre-legal conditio sine qua non - that there is sufficient peace and security to preserve, or upon which to build, a legal order; what Hart might call the minimum content of natural law - self-evident conditions and norms of public order. ${ }^{107}$ Just as an infectious disease might temporarily justify the exercise of emergency executive power at the national level, at the international level the equivalent of infectious diseases or rampant fires in the form of threats to international peace caused by civil wars, protracted internal violence, refugee flows, natural disasters, famine, climate change, arms proliferation, and yes infectious diseases, none of which are breaches of international law per se, are unfortunately prevalent within the international legal order.

The trend in UN Security Council targeted sanctions practice is to move towards widening the concept of "threat to the peace", to enable to be taken to tackle the threat including measures directed at deterring or stopping the violence by non-state actors, with specific focus on those responsible for violations of human rights law and humanitarian law. Assets freezes, travel bans and other targeted measures have been imposed on individuals and groups either because they undermine the peace process or otherwise threaten the peace, but also if they threaten the human security of civilians, manifested in the commission of violations of international law. This is a reflection of a move towards not only securing peace within the state but also in establishing the security of individuals within it. Thus, although appearing to be a form of punishment for breaches of the law, they remain measures aimed at restoring peace

\footnotetext{
${ }^{104}$ UN Doc. S/RES/2134 (2014), para. 37(b).

${ }^{105}$ UN Doc. S/RES/2196 (2015), para. 11.

106 UN Charter, Art. 24(1).

${ }^{107}$ HART, cit. supra note 11, p. 188.
} 
and security but at the local level as well as state level. As well as the example mentioned above, whereby sanctions were taken on this basis against armed groups in the CAR, other examples can be found in Cote D'Ivoire, ${ }^{108}$ Lebanon, ${ }^{109}$ and Sudan. ${ }^{110}$ However, in other instances, targeted measures are more narrowly directed at those regime elites and non-state actors who have threatened the peace; for example in Guinea-Bissau, ${ }^{111}$ Iran,${ }^{112}$ North Korea, ${ }^{113}$ Liberia, ${ }^{114}$ Sierra Leone, ${ }^{115}$ Somalia, ${ }^{116}$ Eritrea, ${ }^{117}$ South Sudan, ${ }^{118}$ and Yemen. ${ }^{119}$

This review of UN, EU and US practice indicates a predominant trend towards targeted sanctions, but also that for the UN and US a primary concern to tackle peace and security and only indirectly violations of international law. Targeted UN sanctions have a clear constitutional basis in the UN Charter. US sanctions are legally problematic as they extend beyond unilateral or "collective" countermeasures or other forms of non-forcible measures of self-help and, thereby, constitute coercive measures in violation of the international legal principle of non-intervention. ${ }^{120}$ The EU's move towards targeted sanctions against regime elites and non-state actors is largely premised on the enforcement of community norms and are, therefore, more readily justifiable as collective countermeasures, although that doctrine remains disputed in international law. ${ }^{121}$

\section{SANCTIONS AS ViOLATIONS OF INTERNATIONAL LAW}

Countermeasures would be unlawful if they are not taken in response to actual breaches of international law, or if they are permanent or disproportionate, making them inherently destabilizing because such judgments are unlikely to be made by an independent court, rather than by the states themselves. Countermeasures and other forms of self-help may therefore be met by counter-countermeasures, as with Russia's response to the measures imposed on it by EU and other states for its intervention in Ukraine. ${ }^{122}$ Although there is justification for imposing collective countermeasures against Russia for its breach of community norms prohibiting aggression, assuming that collective countermeasures are accepted as lawful, in other instances acts of self-help are clearly either spurious or disproportionate, thereby rendering them unlawful acts of coercion. A recent example of this involved Gulf States

${ }^{108}$ For example, UN Doc. S/RES/1572 (2004), para. 9.

${ }^{109}$ For example, UN Doc. S/RES/1636 (2005), para. 3.

${ }^{110}$ For example, UN Doc. S/RES/1591 (2005), para. 3(c).

${ }^{111}$ UN Doc. S/RES/2048 (2012), para. 6.

${ }^{112}$ For example, UN Doc S/RES/1737 (2006), paras. 10 and 12.

${ }^{113}$ For example, UN Doc. S/RES/1718 (2006), para. 8(c).

${ }^{114}$ For example, UN Doc. S/RES/1343 (2001), paras. 2 and 5-7.

${ }^{115}$ For example, UN Doc. S/RES/1132 (1997), para. 5.

${ }^{116}$ For example, UN Doc. S/RES/1844 (2008), paras. 1 and 3.

${ }^{117}$ For example, UN Doc. S/RES/1907 (2009), para. 14.

${ }^{118}$ UN Doc S/RES/2206 (2015), para. 6.

${ }^{119}$ For example, UN Doc. S/RES/2140 (2014).

${ }^{120}$ Embodied, for example, in the Declaration on Principles of International Law concerning Friendly Relations and Cooperation among States in accordance with the Charter of the United Nations, UN Doc. A/RES/25/2625 (1970): "No State may use or encourage the use of economic, political or any other type of measures to coerce another State in order to obtain from it the subordination of the exercise of its sovereign rights and to secure from it advantages of any kind". See also Declaration on the Inadmissibility of Intervention in the Domestic Affairs of States and the Protection of their Independence and Sovereignty, UN Doc. A/RES/20/2131 (1965), para. 2. For analysis of "coercion" as the key component of unlawful intervention see JAMNEJAD and WoOD, "The Principle of Non-Intervention", LJIL, 2009, p. 345 ff., p. 371.

${ }^{121}$ The ILC's Articles did not accept their legality in 2001: see ARSIWA, Art. 54.

122 KRAUSE, "Western Economic and Political Sanctions as Instruments of Strategic Competition with Russia - Opportunities and Risks", in RonZITTI (ed.), cit. supra note 38, p. $270 \mathrm{ff}$. 
imposing an embargo on Qatar in June 2017 for allegedly supporting terrorism, including the demand that Qatar close the Al-Jazeera media network as well as desist in its support for Hamas, the Muslim Brotherhood, Hezbollah, and its relations with Turkey and Iran. These nonforcible measures of self-help taken by Saudi Arabia, the UAE, Bahrain and Egypt demonstrate the weaknesses of self-declared victim states acting as judge, jury and executioner.

Unilateral non-forcible measures of coercion are unlawful unless taken under a secondary rule of international law as countermeasures in response to a violation of a primary rule. On this basis there is no unilateral form of autonomous sanctioning power belonging to states. Collective sanctions are not inherently unlawful and, indeed, Kelsen's view is that they are an integral part of law so that a law consists of a proscription of behaviour and a punishment for misbehaviour. Furthermore, accepting the proposition discussed at the outset of this article, namely that sanctions are imposed by central authorities, the judgement is taken away from individual states and belongs to political organs of international organizations consisting of states but acting in a corporate manner, voting by majority, qualified majority, or unanimity, depending upon the voting rules specified in the constituent treaty.

The inherent legality of sanctions does not immunise decisions to impose them from international law. Sanctions can often be seen to be the cause of violations of international law. At the end of the Cold War before the advent of targeted sanctions, the concern within the UN was to learn from the leaky sanctions regimes against Rhodesia and South Africa of the 1960s and 70s. The move was towards maximizing the effectiveness of general sanctions, with the result that their impact was not only devastating for the innocent, but provided opportunities for the guilty and their backers. In relation to the embargo against the extremely poor country of Haiti in response to the overthrow of the democratically elected government of President Aristide in 1993, the "wealthy elite and the military command were waxing rich off the contraband industry the economic sanctions spawned. The rest of the population, which had been deprived of its popularly elected government and whom we were supposed to be helping, was, without exaggeration, starving to death". ${ }^{123}$

The devastating impact of sanctions against Iraq was well-known and recorded, when the UN Secretary-General's team headed by Marti Ahtisaari reported in March 1991 that the conditions in Iraq were "near apocalyptic", with scant medicines and humanitarian supplies getting through to those in need. ${ }^{124}$ The Security Council responded by adopting the "oil-forfood" Resolution 706 (1991), which "served as the main source of sustenance for 60 percent of Iraq's estimated twenty-seven million people, reducing malnutrition amongst Iraqi children by 50 percent". ${ }^{125}$ Despite the mitigating effects of the mis-managed and corrupted oil-for-food programme, the devastating impact of UN sanctions on the people of Iraq cannot be overstated. The purpose of sanctions changed, from ending the Iraqi occupation of Kuwait, to forcing the regime to disarm. Both purposes were directed at forcing the Iraqi regime to change its behaviour and both concern different aspects of peace and security, and yet the sanctions had a direct effect on the Iraqi people. Sanctions did succeed in keeping the "revenue from Iraq's vast oil wealth out of the hands of Saddam Hussein", preventing the regime from rebuilding its military capabilities, thereby achieving peace and security aims. ${ }^{126}$

${ }^{123}$ REISMAN, "Assessing the Lawfulness of Nonmilitary Enforcement: The Case of Economic Sanctions", AJIL, 1996, p. 37 ff.

124 Chesterman, Franck and Malone, Law and Practice of the United Nations: Documents and Commentary, 2nd ed., Oxford, 2016, p. 376.

125 Ibid., p. 354. VOLCKER, GOLDSTONE and PIETH, Independent Inquiry Committee into the United Nations Oil-for-Food Programme (Final Report), 7 September 2005, p. 179. See further MULLER and MULLER, "Sanctions of Mass Destruction", Foreign Affairs, 1999, p. 3 ff.

${ }^{126}$ CORTRIGHT, LOPEZ, and Gerber-StellingWORTH, "The Sanctions Era", in Weiss and Daws (eds.), The Oxford Handbook on the United Nations, Oxford, 2007, pp. 208-9. 
The oil-for-food programme in Iraq embodied the problem with general sanctions because the need for its creation recognized the inherently violative nature of such measures; they cause death and misery and the resulting attempts at mitigation can only slow that down. The emerging body of evidence about the impact of general sanctions led to criticism by human rights bodies. In a General Comment in 1997, the Committee on Economic Social and Cultural Rights declared that "inhabitants of a given country do not forfeit their basic economic, social and cultural rights by virtue of any determination that their leaders have violated norms relating to international peace and security"; and warned that "lawlessness of one kind should not be met by lawlessness of another kind which pays no heed to the fundamental rights that underlie and give legitimacy to any such collective action". ${ }^{27}$ There was little doubt in the Committee's mind that sanctions caused "significant disruption in the distribution of food, pharmaceuticals and sanitation supplies, jeopardize the quality of food and the availability of clean drinking water, severely interfere with the functioning of basic health and education systems, and undermine the right to work". ${ }^{128}$

Despite the significant impact on the human rights of the peoples of Iraq, it has been argued that human rights laws are inapplicable to those sanctions given that, even if they bind the UN as an inter-governmental organization possessing international legal personality as a matter of customary law, there was no intention by the Security Council to violate those rights. ${ }^{129}$ On the understanding that the Security Council did not intend to violate the rights of the Iraqi people, and, furthermore, that it is necessary to show intent to establish that it had violated international law in this regard, ${ }^{130}$ it still should have foreseen the possibility and, therefore at the very least, it had obligations of due diligence to do all in its power to prevent human rights violations that are likely to result from its actions. ${ }^{131}$

The often-violative nature of unilateral sanctions that go beyond temporary and proportionate countermeasures is shown by the US embargo of Cuba first imposed 1962 in response to Cuba's nationalization of US property and businesses, but tightened considerably with the fall of the Soviet Union and the withdrawal of its support for Cuba in 1991 (meaning an immediate loss of $75-80 \%$ of Cuban trade), ${ }^{132}$ by its incorporation in legislation in the form of the Torricelli and Helms-Burton Acts of 1992 and 1996 respectively. ${ }^{133}$ This tightening of the embargo had dramatic effects on the health of the Cuban population. The government of the United States took cruel advantage of the removal of Soviet support to try and force regime change by a starving population. The effect on life expectancy, the reduction in weight of the average Cuban, the impact on new born babies were all detailed in a report by the independent and respected American Association for World Health (AAWH) in 1997. ${ }^{134}$ For a period of 510 years after the demise of the Soviet Union, when the Cuban population was especially vulnerable, the US legislature chose to continue, indeed intensify, its sanctions against Cuba. That demonstrated sufficient intent to cause deliberate harm and damage to Cuba and to its people, over and above the US exercising its freedom to choose trade partners. Finishing off a

\footnotetext{
${ }^{127}$ Committee on Economic, Social and Cultural Rights General Comment No 8 (1997) on the Relationship between Economic Sanctions and Respect for Economic, Social and Cultural Rights, 12 December 1997.

${ }^{128}$ Ibid. See also Committee on Economic, Social and Cultural Rights, General Comment No 12 (1999),

The Right to Adequate Food (Article 11 of the Covenant), 12 May 1999, para. 37.

129 O'CONNELL, "Debating the Law of Sanctions", EJIL, 2002, p. 63 ff., p. 73.

${ }^{130}$ BRownLIE, System of the Law of Nations: State Responsibility Part I, Oxford, 1983, p. 40.

131 International Law Association, Final Report of Committee on Accountability of International Organizations (2004), p. 15.

132 GoRDON, "Economic Sanctions as Negative Development", Journal of International Development, 2016, p. 474.

${ }^{133}$ LEONGRANDE, "Enemies Evermore: US Policy Towards Cuba After Helms-Burton”, Journal of Latin American Studies, 1997, p. $211 \mathrm{ff}$.

134 AAWH, Denial of Food and Medicine: The Impact of the US Embargo on Health and Nutrition in Cuba, Washington DC, 1997.
} 
weakened Cuban government would inevitably impact upon an even weaker Cuban population, a population who were not comforted by the stated purposes of the Helms-Burton Act to: "assist the Cuban people in regaining their freedom and prosperity"; ensure free and fair elections; protect the United States from Cuban terrorism; address the "theft" of US-owned property; and respond to Cuba's violation of human rights. ${ }^{135}$

One of the unaddressed aspects of when an organization or a state can be held legally responsible for violations of international law is causation - did the wrongful act (in the UN's continuation of sanctions against Iraq in the period 1991-2003, or by the continuation and tightening of the US embargo against Cuba in the period 1992-1996) cause damage to the Iraqi and Cuban peoples? ${ }^{136}$ The decisions to continue the embargoes were clearly attributable to the UN and the United States but did the resulting measures cause the losses suffered by the Iraqi and Cuban populations? The evidence drawn from independent bodies, discussed above, ${ }^{137}$ all clearly point to violations of the socio-economic rights of thousands of individuals in Iraq and Cuba as a result of the measures imposed as a result of decisions by the UN and US respectively. ${ }^{138}$ This was deliberate damage inflicted on Iraq and Cuba, more specifically the populations of those countries, and was not sufficiently mitigated by any of humanitarian exceptions built into the embargoes. ${ }^{139}$

The fact that organizations and states imposing sanctions try to mitigate the effects of such measures on the ordinary people of the target state is indicative that they realize that such powers and rights should be exercised in ways that minimize human rights' violations. For instance, in the decision that imposed a comprehensive embargo against Iraq, the Security Council created an exception for payments and shipments of humanitarian foodstuffs and medical supplies; ${ }^{140}$ but this did not mean that Iraq bought or distributed such supplies to its weakening citizens; hence the advent of the oil-for-food programme some years later. However, although the intention behind the humanitarian exception in sanctions resolutions is to reduce the impact of sanctions on the population, the evidence is that the powerful elites in the target country will take control of the supplies, and that such exceptions will encourage a black market in goods from which elites benefit, thereby strengthening their wealth and position and blunting the positive effects of humanitarian exceptions.

In striving to achieve security aims the UN's general sanctions against countries as a whole have proved too damaging to human rights and, thereby, have not achieved both peace and human rights. In what could perhaps be a developing duty of due diligence to ensure that human rights of the population are not violated, the Council has tried a number of routes including humanitarian exceptions and oil-for-food, but none have sufficiently mitigated the adverse effects of sanctions on the population. The use of lawfully imposed collective sanctions against a whole state seemed to have come to a natural and ugly end in 2003 when Saddam's regime was toppled. It is somewhat ironic that the main example of unlawful unilateral

${ }^{135}$ Helms-Burton Act 1996, cit. supra note 60.

136 STERn, "The Elements of an Internationally Wrongful Act", in CRAWFORD, PELLET and OLLESON (eds.), cit. supra note 18, p. $193 \mathrm{ff}$.

137 See also UN Human Rights Council, Report Submitted by the Personal Representative of the High Commissioner for Human Rights on the Situation of Human Rights in Cuba, 26 January 2007, A/HRC/4/12, para. 7 .

138 GoRdon, Invisible War: The United States and the Iraq Sanctions, Harvard, 2010, pp. 86-102; GORDON, cit. supra note 132, p. 474.

${ }^{139}$ For example, the prohibition of ships trading with Cuba from docking in the US meant that mixed cargoes containing medical supplies, for instance, would not be exported to Cuba: see Cuban government's statement in UN Secretary General's Report, UN Doc. A/71/91 (2016).

${ }^{140}$ UN Doc. S/RES/661 (1991). 
economic sanctions, the US embargo imposed and enforced against Cuba, continues despite overwhelming recognition of its illegality by the UN General Assembly. ${ }^{141}$

It is important, however, for the UN and regional organizations to have a range of nonforcible options in order to address threats to peace and security. In its search for an effective and legitimate non-forcible option, the UN has embraced the idea of "smart" or "targeted" sanctions emerging from the Stockholm Process, ${ }^{142}$ comprising targeted and better designed measures aimed at achieving specific goals in relation to those political and military leaders responsible for the threat, and confining that threat, rather than exerting pressure on a whole country in the hope that this will lead to the regime conceding or collapsing. ${ }^{143}$ Targeted measures are directed at changing the behaviour of those responsible for the threat and, therefore, have greater legitimacy than general sanctions that coerce the innocent into possibly risking everything to change the behaviour of those responsible.

While these new-style targeted sanctions have raised their own human rights concerns in terms of due process, rights to property, privacy and freedom of movement, they are quantitatively far fewer human rights violations when compared with the effects of punitive sanctions imposed against a state and, therefore, against the population of a state. Nonetheless, there is no doubt that effectively implemented targeted sanctions can have a profound effect on the lives of those targeted and their families. In the key UK judgment - the Ahmed case decided by the UK Supreme Court in 2010 - the Court was highly critical of the targeted sanctions regime in terms of its effects of such measures on the lives of individuals. Lord Hope described the impact of the executive orders on targeted individuals and their families as making them effectively "prisoners of the state". ${ }^{144}$

As with general sanctions, there is an on-going debate about the violative nature of targeted sanctions, especially of due process norms. However, the issue has not been resolved in favour of clear rights violations since the listing of individuals can be conceived as an executive or administrative process on the basis of perceived security threats, rather than a judicial one equivalent to a criminal conviction for breaches of core crimes even though the listing results in set of coercive measures, arguably de facto punishment, of those listed. Nevertheless, this has not stopped targeted individuals from claiming before domestic courts, ${ }^{145}$ regional courts, ${ }^{146}$ and in individual complaints to the Human Rights Committee. ${ }^{147}$ While the temporary freezing of an individual's assets could be seen as a preventive administrative measure and, therefore, not subject to full due process protections, the fact that there is a degree of permanence in a number of listings means that there should be avenues for

${ }^{141}$ For example, UN Doc. A/RES/72/4 (2017), adopted by 191 votes to 2 (US and Israel). For the argument that unilateral embargoes may be lawful acts of retorsion see RUYS, cit. supra note 8, pp. 26-27. See statement by the International Court of Justice in Military and Paramilitary Activities in and Against Nicaragua (Nicaragua $v$. United States of America), Judgment of 27 June 1986, ICJ Reports 1986, p. 14 ff., para. 245. Without offering reasons, the Court found that a US trade embargo imposed on Nicaragua did not breach the customary international law principle of non-intervention.

142 WALlENSTEEN, STAIBANO and ERIKSSON (eds.), Making Targeted Sanctions Effective: Guidelines for the Implementation of UN Policy Options, Uppsala, 2003, a report by Uppsala University presented by Sweden to Security Council: see UN Doc. S/4713 mtg (2003).

${ }^{143}$ ChESTERMAN, FRANCK and MALONE, cit. supra note 124, p. 343.

${ }^{144}$ Her Majesty's Treasury v. Mohammed Jabar Ahmed and Others, [2010] UKSC 2, para. 4.

${ }^{145}$ For example, Abdelrazik v. Canada (Minister of Foreign Affairs), [2010] 1 FCR 267.

146 Joined Cases. C-402/05 P and C-415/05 P, Yassin Abdullah Kadi and Al Barakaat International Foundation v. Council and Commission, ECR, 2008, I-06351, para. 334; European Court of Human Rights, Nada v. Switzerland, Application No. 10593/08, Judgment of 12 September 2012; European Court of Human Rights, Case of Al-Dulimi and Montana Management Inc. v. Switzerland, Application No. 5809/08, Judgment of 21 June 2016.

${ }^{147}$ Nabil Sayadi and Patricia Vinck v. Belgium, Communication No 1472/2006, 29 December 2008, 16 IHHR 427. 
challenging such decisions. Temporary preventive targeted sanctions imposed by the UN Security Council in response to specific threats might enable states to modify their human rights obligations to the extent of suspending any conflict with their obligations arising under the UN Charter. ${ }^{148}$ However, targeted sanctions imposed by states pursuant to the legislative resolutions of the Security Council, principally Resolution 1373 (2001), ${ }^{149}$ do not fit the model of executive decisions necessitating the temporary trumping of human rights obligations. Furthermore, obligations arising from sanctions imposed by states unilaterally or by reason of a decision of a regional organization cannot claim to have primacy over human rights obligations owed by states.

Targeted sanctions may be adopted against regime and regime elites, and non-state actors such as those measures adopted in 1999 and 2000 against the Taliban and Al-Qaida. Criticism of their incompatibility with human rights norms by judicial bodies has led to the Security Council creating an Ombudsperson to consider requests for delisting and to make recommendations to the Security Council to that end. It is interesting to note that review by the Ombudsperson established by Security Council Resolution 1904 in 2009 only applies to those on the Al-Qaida Sanctions List as administered by the 1267 Committee and not to any lists beyond that, including the Taliban list. This seemingly curious anomaly is probably explained by the overarching pragmatism of the Security Council on the matter of accountability for wrongly listing individuals; that complaints to international, regional and judicial bodies have derived largely from the 1267 list and the creation of the office of the Ombudsperson is a response to that development. ${ }^{150}$

The lack of remedies elsewhere in the UN system for wrongly listed individuals puts the creation of the Ombudsperson in perspective, but it also fits the apparent prevailing view in the Security Council that such measures are administrative ones taken in response to an international threat caused by the activities of international terrorist organizations and, therefore, any remedial measures should only be of a limited administrative nature. However, long-term listing arguably constitutes a form of punishment that raises issues of legal remedies based on violations of due process norms located in the international human rights obligations of states. The fact that those states are simultaneously under duties deriving from the UN Charter to carry out decisions of the Security Council is one of the pressing issues of international law that cannot be solved by the simple uncritical application of Article 103 . $^{151}$

The creation of more transparent listing procedures and, in particular, a non-judicial mechanism to review petitions at the UN level is no minor event, given the almost complete unaccountability of the Security Council for its actions in the past. However, the Ombudsperson is not only limited to those on the Al-Qaida list, but she cannot remove the listed individual given that the process consists of a dialogue with the petitioner, and then the presentation of arguments by the Ombudsperson to the 1267 Committee, which then decides whether or not to accept request. With the ultimate decision in the hands of the 1267 Committee, the very originator of the challenged sanctions, the latest development has not gone far enough in terms of providing a proper remedy at the international level.

\section{CONCLUSION}

${ }^{148}$ UN Charter, Art. 103.

${ }^{149}$ UN Doc. S/RES/1373 (2001).

150 See criticism of the unevenness of access to remedies by the Ombudsperson, Kimberly Prost, in a briefing by her at the Security Council's Open Debate on "Working Methods of the Security Council" (UN Doc. S/2014/725) on the topic of: "Enhancing Due Process in Sanctions Regimes", 23 October 2014.

${ }^{151}$ LIIVOJA, "The Scope of the Supremacy Clause of the United Nations Charter", ICLQ, 2008, p. 583 ff., p. 612 . 
It has been argued that accountability mechanisms tend to improve at the international level in response to crises, ${ }^{152}$ even in the hard core of security matters dealt with by the Security Council, where it is likely that future improvements will be made to delisting mechanisms as the UN adjusts its sanctioning processes towards increased human rights compliance. Given that the Security Council has now imposed targeted sanctions against a range of regime elites and non-state actors the demands for redress will inevitably increase. Collective sanctions, although lawful, have to be adjusted to fit within the broader international legal order.

Sanctions have changed over the decades: they have become more humane, they have become more common, but they remain exceptional to international law in the sense that they are largely imposed to enforce peace not law. Given the centrality of sanctions to any legal system there is clearly significant adjustments to be made to place sanctions within the parameters of international law, ensuring that they do not themselves violate fundamental norms. This is not to forget the Security Council's primary responsibility for peace and security or to argue that it should be solely an executive enforcer of international law. International law is not developed sufficiently to do that, nor is the UN itself based on a separation of powers.

What has been argued is that there is a need to conceptualise "peace" and "security" as normative concepts, accept their protection as public order norms in the international legal sphere, and work on their fit, their balance, and their position within the existing international legal fabric. Institutional practice on the nature and purposes of collective sanctions, reviewed above, is inconsistent; for example, collective sanctions taken in response to violations of existing core norms of the international legal order, as practised by the EU in particular, are not matched sufficiently by the UN Security Council at the universal level, due to the lack of consensus within the permanent membership as to when intervention in member states is justified.

The development of the idea of a "responsibility to protect" in cases of core crimes has helped to highlight inadequacy at the UN level, when at the very least non-forcible targeted measures should be imposed against those responsible for violating core crimes or for failing to prevent them. ${ }^{153}$ A serious breach of international law, whether of norms protecting "peace", "security", "genocide", "crimes against humanity", extensive "war crimes", or "ethnic cleansing", has to be met with effective targeted sanctions in the majority of instances if international law is to raise itself above simply being a collection of primary rules proscribing behaviour, but not containing within those rules sanctions to counter such behaviour.

Collective sanctions imposed by legitimate centralized institutions, either universal or regional, are not only inherently lawful but are of a different order to the secondary rules of responsibility that permit states to apply inherently unlawful countermeasures in responses to breaches of their international rights by other states, a right that can easily be abused and become unbridled economic coercion as the enduring embargo of Cuba by the US demonstrates. It follows there is no autonomous right belonging to states to impose sanctions beyond the limited forms of non-forcible self-help recognized primarily in the doctrine of countermeasures, despite extensive US practice and the suggestion from the UK government that it will also be claiming such rights on its departure from the EU in 2019.

Collective countermeasures, as responses to breaches of core crimes, are understandable responses to breaches of core international crimes and as such can be categorised as "public"

${ }^{152}$ MULGAN, “AWB and Oil for Food: Some Issue of Accountability”, in FARRALL and RUBENSTEIN (eds.), Sanctions, Accountability and Governance in a Globalised World, Cambridge, 2009, p. 334 ff., p. 334.

${ }^{153}$ For example, non-forcible measures have not been imposed by the UN against the Syrian government, despite UN reports finding "crimes against humanity" have regularly been committed in Syria. The Security Council's non-forcible measures have been directed against ISIL and other terrorist groups, for example, in UN Doc. S/RES/2170 (2014); UN Doc. S/RES/2199 (2015); UN Doc. S/RES/2249 (2015). 
responses to assaults on the international legal order, rather than the normal form of "private" countermeasures imposed in a strictly bilateral relationship. ${ }^{154}$ However, given the inherent weaknesses in unilateral and subjective judgements by states as to when to impose such nonforcible measures, they can only ever be an unstable and, therefore, temporary stepping stone toward collective, centrally imposed, sanctions.

${ }^{154}$ See generally, DAVIDOwICZ, "Public Law Enforcement without Public Law Safeguards? An Analysis of State Practice on Third-Party Countermeasures and their Relationship to the UN Security Council", BYIL, 2006, p. $333 \mathrm{ff}$. 